\title{
PENGOLAHAN SUSU SAPI MENJADI SUSU PASTEURISASI UNTUK MENINGKATKAN NILAI SUSU DAN DAYA JUAL
}

\author{
Nisa'us Sholikah*, Ahmad Abdul Mufid, Andika Septian Bachrul, Tony Rachmad \\ Hidayat, Yulian Yoga \\ Fakultas Peternakan, Universitas Islam Malang \\ *korespondensi email: nisaus.sholikah@unisma.ac.id
}

\begin{abstract}
ABSTRAK
Susu merupakan bahan makanan yang bernilai gizi tinggi yang diperoleh dari hasil pemerahan hewan seperti sapi, Kerbau, Kuda, Kambing dan Unta.Susu sapi mudah rusak bila penanganannya kurang baik, Sehingga mempunyai masa simpan relatif singkat.Di Dusun Sumber Wangi Desa Donowarih, Kecamatan Karangploso, Kabupaten Malang merupakan desa yang terletak di Daerah Pegunungan, dimana terletak di Lereng Gunung Mujur yang memiliki potensi Hutan pinus dan Perkebunan Kopi dan memiliki banyak jenis rumput yang beraneka ragam. Di Desa ini memiliki banyak ternak sapi. Di Dusun Sumber Wangi Desa Donowarih, Kecamatan Karangploso, Kabupaten Malang terdiri dari 36 KK sabagian warga bermata pencarian sebagai peternak sapi perah, dan sebagian bermata pencaharian sebagai petani. Dari sini kami melakukan sosialisasi secara langsung kepada masyarakat tentang produksi susu dan bagaimana cara pengelolahan dan masa simpan susu secara alami. Kebanyakan masyarakat setempat belum tau tata cara pengelolahan susu secara benar. Masyarakat yang berternak sapi perah ada kendala kelebihan produksi susu yang sebagian besar sudah disetorkan di KUD, sedangkan penyetoran susu di KUD dibatasi, untuk menangani sisa produksi susu sapi, langkah yang paling tepat yaitu dengan mengawetkan susu sapimelalui proses pengolahan dan meningkatkan konsumsi susu olahan oleh masyarakat, salah satunya yaitu melalui proses Pasteurisasi susu.Berdasarkan hasil pengamatan, diduga dari 38 orang yang ikut serta dalam sosialisasi dan pelatihan dalam pembuatan susu pasteurisasi rasa coklat dan stroberi banyakyang suka susu pasteurisasi rasa coklat dari pada rasa stroberi. Diharapkan dari hasil kegiatan ini masyarakat mampu meningkatkan perekonomian melalui hasil olahan susu.
\end{abstract}

Kata Kunci: peternak; sapi perah; susu sapi; pasteurisasi

\section{PENDAHULUAN}

Susu merupakan bahan makanan yang bernilai gizi tinggi yang diperoleh dari hasil pemerahan hewan seperti sapi, Kerbau, Kuda, Kambing dan Unta. Komponen terpenting dalam air susu adalah protein, Lemak, Vitamin, Mineral, Laktosa serta enzim-enzim dan beberapa jenis mikroba yang bermanfaat bagi kesehatan sebagai probiotik (Thai Agricultural Standard, 2008; Arief et al., 2018).

Susu segar merupakan bahan makanan yang bergizi tinggi karena di dalam susu segar mengandung berbagai zat makanan yang lengkap dan seimbang seperti protein, lemak, karbohidrat, mineral, dan vitamin yang sangat dibutuhkan oleh tubuh manusia. Nilai gizi susu yang menyebabkan susu menjadi medium yang sangat disukai oleh mikroorganisme yang mendorong pertumbuhan dan perkembangan mikroba, Sehingga dalam waktu yang 
singkat susu menjadi tidak layak dikonsumsi bila tidak ditangani secara tepat dan benar. Salah satu cara pengelolahan susu agar tetap bertahan lama dalam waktu tertentu adalah dengan pasteurisasi (Chrisna Wulandari et al., 2016; Noerhayati \& Sulo, 2018).

Susu pasteurisasi menurut SNI 01-3951-1995 adalah susu yang telah mengalamiproses pemanasan pada temperature $720 \mathrm{C}$ minimum selama 15 detik atau pemanasan pada 63-660C selama 30 menit, kemudian segera didinginkan sampai 100C, Selanjutnya diperlukan secara aseptik dan disimpan pada suhu maksimum 4,40C (et al., 2017). Proses penanganan, Pengolahan, Pengawetan, dan penyimpanan bahan pangan yang kurang baik dapat mengakibatkansusu mudah rusak. Kontaminasi mikroorganisme seperti Staphylococcus aureus ke dalam susu tidak menyebabkan perubahan fisik susu, sehingga keberadaannya tidak disadari konsumen. Selain itu mikroorganisme yang sering digunakan sebagai indicator sanitasi dalam pangan yaitu Escherichia coli. Adanya Escherichia coli di dalam suatu makanan menunjukan telah terjadi kontaminasi karena sanitasi yang tidak baik selama persiapan produk maupun pengolahan spora mikroorganisme pathogen tidak hilang oleh pasteurisasi, oleh karena itu upaya untuk menjaga kualitas susu pasteurisasi dengan menyimpannya dalam suhu rendah (Hutagaol et al., 2013).

Di Dusun Sumber Wangi Desa Donowarih, Kecamatan Karangploso, Kabupaten Malang merupakan desa yang terletak di Daerah Pegunungan, dimana terletak di Lereng Gunung Mujur yang memiliki potensi Hutan pinus dan Perkebunan Kopi dan memiliki banyak jenis rumput yang beraneka ragam. Di Desa ini memiliki banyak ternak sapi. Di Dusun Sumber Wangi Desa Donowarih, Kecamatan Karangploso, Kabupaten Malang yang terdri dari $36 \mathrm{KK}$ sabagian warga bermata pencarian sebagai peternak sapi perah, dan sebagian bermata pencaharian sebagai petani. Kebanyakan masyarakat setempat belum tau tata cara pengelolahan susu secara benar. Masyarakat yang berternak sapi perah ada kendala kelebihan produksi susu yang sebagian besar sudah disetorkan di KUD, sedangkan penyetoran susu di KUD dibatasi, Untuk menangani sisa produksi susu sapi, langkah yang paling tepat yaitu dengan mengawetkan susu sapi melalui proses pengolahan serta meningkatkan konsumsi susu olahan oleh masyarakat, salah satunya yaitu melalui proses Pasteurisasi susu.Dari sini kami melakukan sosialisasi secara langsung kepada masyarakatbtentang produksi susu dan bagaimana cara pengelolahan dan memperpanjang masa simpan susu secara alami. Oleh karena itu, tujuan KSM Tematik ini adalah mengenalkan hasil olahan susu sapi kepada masyarakat setempat.

\section{METODE}

Kegiatan ini dilaksanakan pada tanggal 20 Februari 2021, Bertempat di Dusun Sumber Wangi Desa Donowarih Karangploso Malang. Tepat pada pukul 16:30 - 18:00 WIB. Alat-alat yang digunakan dalam pembuatan susu pasteurisasi antara lain adalah kompor, panci, pengaduk, dan termometer. Sedangkan bahan-bahan yang digunakan pada pembuatan susu pasteurisasi adalah susu sapi segar, gula, perisa rasa coklat dan stroberi. Metode yang kami gunakan adalah metode sosialisasi dan pelatihan dalam pembuatan susu pasteurisasi aneka 2 rasa yaitu coklat dan strowberi. Serta menguji tingkat kesukaan antara susu pasteurisasi rasa coklat dan stroberi.

\section{HASIL DAN PEMBAHASAN}

Kerusakan pada susu disebabkan oleh terbentuknya asam laktat sebagai hasil fermentasi laktosa oleh Escherichia coli Fermentasi oleh bakteri ini akan menyebabkan aroma susu menjadi berubah dan tidak disukai oleh konsumen. Untuk meminimalkan kontaminasi oleh mikroorganisme dan menghambat pertumbuhan bakteri pada susu agar 
dapat disimpan lebih lama maka penanganan sesudah pemerahan hendaknya menjadi perhatian utama Peternak.

Salah satu cara yang tepat untuk mencegah terjadinya kerusakan pada susu yaitu dengan cara pemanasan atau Pasteurisasi baik dengan suhu tinggi maupun suhu rendahyang dapat diterapkan pada peternak. Dengan pemanasan ini diharapkan mampu membunuh bakteri patogen yang membahayakan kesehatan manusia dan meminimalisasi perkembangan bakteri lain, baik selama pemanasan maupun pada saat penyimpanan.

Mahasiswa melakukan kegiatan sosialisasi dan pelatihan kepada warga Dusun Sumber Wangi Desa Donowarih, Kecamatan Karangploso, Kabupaten Malan, karena setelah melakukan survey, diketahui bahwa kebanyakan masyarakat yang berternak sapi perah pada saat kelebihan produksi susu, masih belum tau tata cara pengelolahan susu dengan benar. Dengan adanya kegiatan ini diharapkan masyarakat mampu memahami sekaligus dapat meningkatkan perekonomian dengan cara pengolahan susu pasteurisasi dengan baik dan benar.

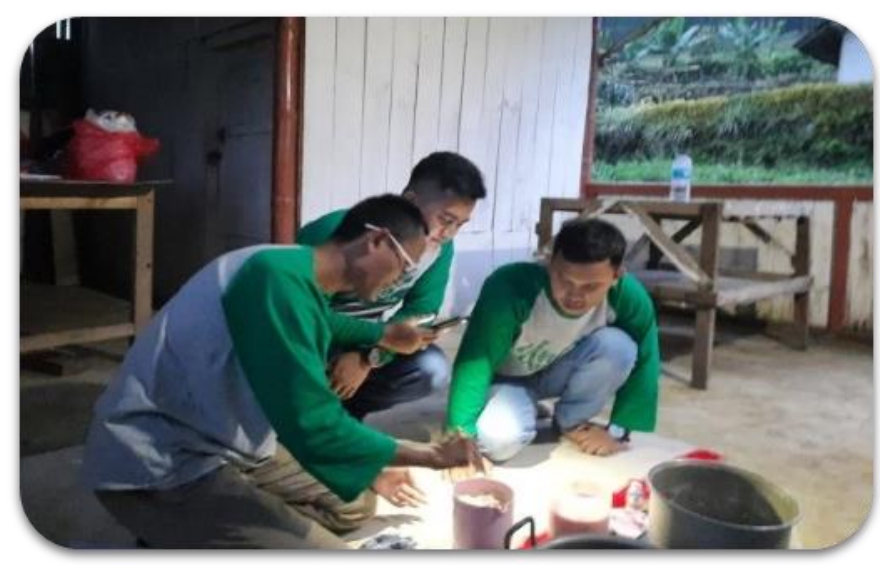

Gambar 1. Pembuatan susu pasteurisasi

Proses pembuatan susu pasteurisasi yang dilakukan adalah dengan memanaskan suhu pada suhu $62^{\circ} \mathrm{C}$ selama kurang lebih 30 menit. Bila ingin cepat dapat menggunakan suhu kisaran antara $72^{\circ} \mathrm{C}$ selama kurang lebih 15 detik lamanya (Sabil, 2015). Pasteurisasi tidak dapat mematikan bakteri non pathogen, terutama bakteri pembusuk. Susu pasteurisasi bukan merupakan susu awet. Penyimpana susu pasteurisasi dilanjutkan dengan metode pendingin pada suhu maksimal $10^{\circ} \mathrm{C}$ memperpanjang daya simpan susu pasteurisasi. Mikroba pembusuk tidak dapat tumbuh dan berkembang pada suhu $3-10^{\circ} \mathrm{C}$ (Wardana, 2012).

Pada kegiatan pembuatan susu pasteurisasi menggunakan metode holding dimana proses pemanasan susu pada suhu kisaran antara $60-63^{\circ} \mathrm{C}$ selama 30 menit. Metode ini menggunakan 2 panci yang berbeda ukuran dengan tujuan susu tidak tersentuh langsung oleh api sehingga kandungan nutrisinya tetap utuh. Metode ini menggunakan thermometer suhu dengan tujuan mengetahui suhu pada proses pembuatan susu pasteurisasi. 


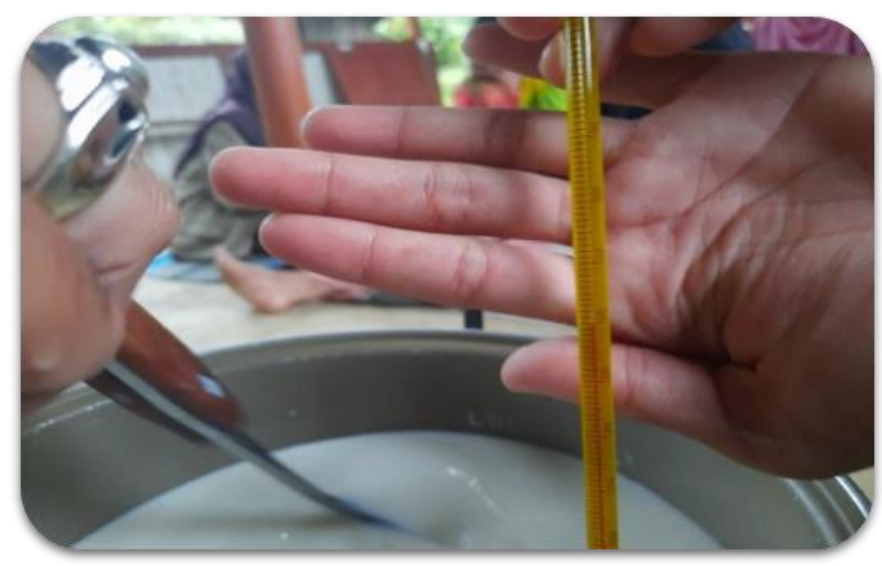

Gambar 2. Pengecekan suhu susu dengan termometer

Tjahjadi \& Marta (2011) menyatakan bahwa tujuan pengolahan susu pasteurisasi adalah sebagai berikut (1) Membunuh semua bakteri pathogen (penyebab penyakit) yang umumnya dijumpai pada bahan pangan, yaitu bakteri pathogen yang berbahaya ditinjau dari kesehatan masyarakat, (2) Memperpanjang daya simpan bahan pangan dengan jalan mematikan bakteri pembusuk dan menonaktifkan enzim pada bahan pangan yang asam (pH $<4,5)$. Hasil dari KSM Tematik kelompok 03 meliputi pengamatan kesukaan susu pasteurisasi rasa coklat dan stroberi. seperti pada Tabel 1.

Tabel 1. Perbandingan tingkat kesukaan susu pasteurisasi rasa coklat dan strowberi

\begin{tabular}{ccc}
\hline Jumlah peserta & $\begin{array}{c}\text { Tingkat kesukaan susu } \\
\text { pasteurisasi rasa coklat }\end{array}$ & $\begin{array}{c}\text { Tingkat kesukaan susu } \\
\text { pasteurisasi rasa } \\
\text { strowberi }\end{array}$ \\
\hline 38 Orang & 21 Orang & 17 Orang \\
\hline
\end{tabular}

Berdasarkan hasil pengamatan, diduga dari 38 orang yang ikut serta dalam sosialisasi dan pelatihan dalam pembuatan susu pasteurisasi rasa coklat dan stroberi banyak yang suka susu pasteurisasi rasa coklat dari pada rasa stroberi. Diharapkan dari hasil kegiatan ini masyarakat mampu meningkatkan perekonomian melalui hasil olahan susu.

\section{KESIMPULAN}

Kegiatan KSM yang telah kami lakukan, diperoleh kesimpulan bahwa warga Dusun Sumber Wangi belum mempunyai pengetahuan dan wawasan tentang pengolahan susu sapi. Dengan adanya kegiatan ini maka diharapkan dapat meningkatkan nilai ekonomi warga setempat. Perlu adanya perhatian dan bimbingan dari Pemerintah agar warga bisa mengembangkan hasil pengolahan susu serta perlu adanya tindakan lanjut agar perekonomian warga meningkat.

\section{DAFTAR RUJUKAN}

Arief, R. W., Santri, N., \& Asnawi, R. (2018). Pengenalan Pengolahan Susu Kambing Di Kecamatan Sukadana Kabupaten Lampung Timur. Jurnal Teknologi \& Industri Hasil Pertanian, 23(1), 45-56. https://doi.org/10.23960/jtihp.v23i1.45-56

Chrisna Wulandari, D., Nurdiana, \& Rahmi, Y. (2016). Identifikasi Kesempurnaan Proses Pasteurisasi Ditinjau dari Total Bakteri serta Kandungan Protein dan Laktosa pada Susu Pasteurisasi Kemasan Produksi Pabrik dan Rumah Tangga di Kota Batu. Majalah Kesehatan, 3(3), 144-151. https://doi.org/10.21776/ub.majalahkesehatan.003.03.5 Hutagaol, F. V. A., Purnawarman, T., \& Afiff, U. (2013). Kualitas Mikrobiologis Susu Sebelum 
dan Sesudah Pasteurisasi. Institut Pertanian Bogor (IPB).

Noerhayati, E., \& Sulo, B. D. (2018). IbM Kelompok Peternak Sapi Desa Hadiwarno Kab. Pacitan Dalam Pemanfaatan Energi Alternatif. JIPEMAS: Jurnal Inovasi Hasil Pengabdian Masyarakat, 1(1), 25-28. https://doi.org/10.33474/jipemas.v1i1.1476

Sabil, S. (2015). Pasteurisasi High Temperature Short Time (HTST) Susu Terhadap Listeria Monocytogenes pada Penyimpanan Refrigerator. Universitas Hasanuddin.

Thai Agricultural Standard. (2008). Raw Goat Milk. National Bureau of Agricultural Commodity and Food Standards Ministry of Agriculture and Cooperatives.

Tjahjadi, C., \& Marta, H. (2011). Pengantar teknologi pangan. Universitas Padjajaran, Bandung.

Wardana, A. S. (2012). Teknologi Pengolahan Susu. Fakultas Teknologi Pertanian, Universitas Slamet Riyadi Surakarta.

Wulandari, Z., Taufik, E., \& Syarif, M. (2017). Kajian Kualitas Produk Susu Pasteurisasi Hasil Penerapan Rantai Pendingin. Jurnal Ilmu Produksi Dan Teknologi Hasil Peternakan, 5(3), 94-100. https://doi.org/10.29244/jipthp.5.3.94-100 